\title{
Impact of Social determinants on Well-Being of Women
}

\author{
Ella Rani*, Vandana Verma and Binesh Goyat \\ Department of Extension Education and Communication Management, \\ COHS CCS HAU, Hisar, Haryana, India \\ *Corresponding author
}

\section{A B S T R A C T}

\section{Keywords \\ Social determinants, Well-being, Psychological, Women and Impact \\ Article Info \\ Accepted: \\ 26 March 2018 \\ Available Online: \\ 10 April 2018}

\section{Introduction}

Women play a very important role in various farm operations both as cultivators and agricultural labourers. They participate in the most of the agricultural operations like sowing, weeding, irrigation, fertilizing harvesting etc. Not only this after a days hard work when they come back home they have to cook meal for the family. However, the female work participation conceals a great deal of work done and time spent by rural women in farm, dairy and home activities. A lack of available gender disaggregated data means that women's contribution to agriculture in particular is poorly understood and their specific needs ignored in development planning. However, still there remain a wide gap in their knowledge and skills which are needed for contribution to fullest extent. Rural women generally have poor access to agricultural information and services. Today sufficient emphasis has now been laid on planned and desirable changes through training programmes and rural development programmes to improve the socio economic and psychological well-being of rural women. The best way to make use of natural and potential capabilities of farm women is to provide them with opportunities for selfdevelopment through training, which means transfer of technologies for improving the existing knowledge and skill, enhanced capabilities, confidence and decision making 
which improves the competency and help in getting assured income from the farming enterprises towards psychological well-being. The mission of the project was to empower women farmers to reduce their drudgery in the context of Agriculture, animal husbandry and to enhance their entrepreneurial skills for improved psychological wellbeing. The present Paper entitled "Assessment of social derivers for psychological wellbeing of women" was prepared with the objective to study the impact of project on the respondents in terms of income, self-esteem, confidence building, capacity building, decision making, nutrition and health status and social empowerment by rural women.

\section{Materials and Methods}

The Hisar district covering Haryana state was selected purposively for the purpose of investigation where National Agricultural Technology Project (NATP) on "Empowerment of women in Agriculture" was carried for three years by the Department of Home Science Extension Education (CoCenter), CCS Haryana Agriculture University, Hisar (Haryana). A sample of 180 beneficiaries from each of the villages covered under project was drawn randomly from experimental group.

\section{Results and Discussion}

Impact assessment of social determinants on psychological wellbeing of women

\section{Economic wellbeing}

It is apparent from the data in Table 1. Actual beneficiaries reported increase in their income wellbeing as a result of being beneficiaries of NATP, which got first rank (2.88). Second rank (2.87) was given to the increase in the expenditure (2.87) by the respondents' consequent of the impact of project. It was followed by saving (2.83), investment (2.69), marketing (2.48), control over income (2.46) and returning of loan (2.37) as result of impact of the project on the actual beneficiaries. Conclusively, the above results showed that the project under reference succeeded in increasing income, expenditure and saving of the respondents. It also provided additional and regular income to its beneficiaries. The findings are inconsonance with the result of Hirevenkanagoudar et al., (2005) and Depti (2008).

\section{Confidence wellbeing}

Information on confidence wellbeing as impact on account of project is presented in Table 2. On the basis of mean scores, it can be inferred that respondents reported on confidence building to deal with family issues (rank $\mathrm{I}^{\text {st }}$ ) increasing in dealing with SHG meetings ( $\mathrm{II}^{\text {nd }}$ rank), dealing societal and other issues (III ${ }^{\text {rd }}$ rank) and dealing with private institution/organizations (IV ${ }^{\text {th }}$ rank).

\section{Decision making}

The results regarding impact of the project on decision making pattern, of the respondents are presented in Table 3. It was found that a huge majority of the respondents reported an increase in make decision regarding buying and selling of valuables like grain, animals, which got first rank (2.88). Increase in decision making was reported in making decision for children's education (2.87), family resource planning (2.83), property and household goods (2.71) and others (social/festivals/voting etc.) (2.68) on account of them being beneficiaries of the project.

Further, an increase in making decision about daily household expenditure/ requirements (2.65), family and social functions requirements (2.65) and family and social functions requirements (2.41) was reported by the respondents as point of impact of the project. 
Table.1 Economic wellbeing of the respondents

\begin{tabular}{|c|c|c|c|c|c|c|c|}
\hline \multirow{3}{*}{$\begin{array}{l}\mathrm{Sr} \\
\mathrm{N} \\
\mathrm{o}\end{array}$} & \multirow{3}{*}{ Statement } & \multirow{2}{*}{\multicolumn{3}{|c|}{ Response }} & \multirow{3}{*}{$\begin{array}{l}\text { Total } \\
\text { Score }\end{array}$} & \multirow{3}{*}{ Mean Score } & \multirow{3}{*}{$\begin{array}{r}n=180 \\
\text { Rank }\end{array}$} \\
\hline & & & & & & & \\
\hline & & $\begin{array}{c}\text { Increase } \\
\text { (3) }\end{array}$ & $\begin{array}{l}\text { Same } \\
\text { (2) }\end{array}$ & $\begin{array}{c}\text { Decrease } \\
\text { (1) }\end{array}$ & & & \\
\hline 1. & Income & $159(471)$ & $21(42)$ & 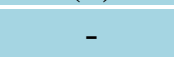 & 519 & 2.88 & I \\
\hline 2. & Expenditure & $157(471)$ & $23(46)$ & - & 517 & 2.87 & II \\
\hline 3. & Saving & $150(450)$ & $30(60)$ & - & 510 & 2.83 & III \\
\hline 4. & Investment & $145(435)$ & $15(45)$ & $20(20)$ & 485 & 2.69 & IV \\
\hline 5. & Marketing & $87(261)$ & $93(186)$ & $0(0)$ & 447 & 2.48 & V \\
\hline 6. & Control over income & $90(270)$ & $83(166)$ & $7(7)$ & 443 & 2.46 & VI \\
\hline 7. & Returning of loan & 71(213) & 104(208) & $6(6)$ & 427 & 2.37 & VII \\
\hline
\end{tabular}

Table. 2 Confidence wellbeing aspects

\begin{tabular}{|c|c|c|c|c|c|c|c|}
\hline \multirow{3}{*}{$\begin{array}{l}\text { Sr } \\
\text { No. }\end{array}$} & \multirow{3}{*}{ Statement } & & & & & & $=180$ \\
\hline & & \multicolumn{3}{|c|}{ Response } & \multirow{2}{*}{$\begin{array}{l}\text { Total } \\
\text { Score }\end{array}$} & \multirow{2}{*}{$\begin{array}{l}\text { Mean } \\
\text { Score }\end{array}$} & \multirow{2}{*}{ 竎 } \\
\hline & & $\begin{array}{l}\text { Increase } \\
\text { (3) }\end{array}$ & Same (2) & $\begin{array}{l}\text { Decrease } \\
\text { (1) }\end{array}$ & & & \\
\hline 1. & $\begin{array}{l}\text { Confidence to deal with } \\
\text { family issues }\end{array}$ & $162(486)$ & $18(36)$ & $20(20)$ & 522 & 2.90 & I \\
\hline 2. & $\begin{array}{l}\text { Dealing with SHG } \\
\text { meeting }\end{array}$ & 153(459) & $27(54)$ & - & 513 & 2.85 & II \\
\hline 3. & $\begin{array}{l}\text { Dealing private } \\
\text { institution/ organization }\end{array}$ & $66(198)$ & $114(228)$ & - & 426 & 2.36 & IV \\
\hline 4. & $\begin{array}{l}\text { Dealing society and } \\
\text { other issues }\end{array}$ & $135(405)$ & $45(90)$ & - & 495 & 2.75 & III \\
\hline
\end{tabular}

Table.3 Decision making aspects

\begin{tabular}{|l|l|l|l|l|c|c|c|}
\hline $\begin{array}{l}\text { Sr } \\
\text { No. }\end{array}$ & \multicolumn{3}{|c|}{ Response } & $\begin{array}{c}\text { Total } \\
\text { Score }\end{array}$ & $\begin{array}{c}\text { Mean } \\
\text { Score }\end{array}$ & Rank \\
\hline & $\begin{array}{l}\text { Increase } \\
(3)\end{array}$ & Same (2) & $\begin{array}{c}\text { Decrease } \\
(1)\end{array}$ & & & \\
\hline 1. & Children's education & $157(471)$ & $23(46)$ & 0 & 517 & 2.87 & II \\
\hline 2. & Family resource planning & $150(450)$ & $30(60)$ & 0 & 510 & 2.83 & III \\
\hline 3. & $\begin{array}{l}\text { Buying and selling valuable } \\
\text { like grain, animal etc. }\end{array}$ & $159(477)$ & $21(42)$ & 0 & 519 & 2.88 & I \\
\hline 4. & $\begin{array}{l}\text { Property and household } \\
\text { goods }\end{array}$ & $129(387)$ & $51(102)$ & 0 & 489 & 2.71 & IV \\
\hline 5. & $\begin{array}{l}\text { Daily household } \\
\text { expenditure/ requirements }\end{array}$ & $117(351)$ & $63(126)$ & 0 & 477 & 2.65 & VI \\
\hline 6. & $\begin{array}{l}\text { Family and social functions } \\
\text { requirements }\end{array}$ & $83(249)$ & $89(178)$ & $8(8)$ & 435 & 2.41 & VII \\
\hline 7. & $\begin{array}{l}\text { Other (social festival/ voting } \\
\text { etc }\end{array}$ & $83(249)$ & $89(178)$ & $8(8)$ & 435 & 2.41 & VI \\
\hline
\end{tabular}


Table.4 Nutrition and health wellbeing

\begin{tabular}{|l|l|c|c|c|c|c|c|}
\hline $\begin{array}{l}\text { Sr. } \\
\text { No. }\end{array}$ & Statement & $\begin{array}{c}\text { Response } \\
\text { Increase } \\
(3)\end{array}$ & $\begin{array}{c}\text { Same } \\
(2)\end{array}$ & $\begin{array}{c}\text { Decrease } \\
(1)\end{array}$ & $\begin{array}{c}\text { Total } \\
\text { Score }\end{array}$ & $\begin{array}{l}\text { Mean } \\
\text { Score }\end{array}$ & Rank \\
\hline 1. & $\begin{array}{l}\text { Expenses on health care } \\
132(396)\end{array}$ & $48(96)$ & 0 & 492 & 2.73 & I \\
\hline 2. & $\begin{array}{l}\text { Sale food item (milk/ } \\
\text { ghee/grain) }\end{array}$ & $138(414)$ & $36(72)$ & $6(6)$ & 492 & 2.73 & I \\
\hline $3 . \quad \begin{array}{l}\text { Expenditure on ghee items } \\
\text { (Purchase of vegetable/ } \\
\text { grocery etc) }\end{array}$ & $55(165)$ & $62(124)$ & $63(63)$ & 352 & 1.95 & III \\
\hline $4 . \quad \begin{array}{l}\text { Availability of milk for } \\
\text { family consumption }\end{array}$ & $100(300)$ & $68(136)$ & $12(12)$ & 448 & 2.48 & II \\
\hline
\end{tabular}

Table.5 Impact of project in terms of social empowerment

\begin{tabular}{|c|c|c|c|c|c|c|c|}
\hline \multirow{2}{*}{$\begin{array}{l}\text { Sr. } \\
\text { No. }\end{array}$} & \multirow[t]{2}{*}{ Statement } & \multicolumn{3}{|c|}{ Response } & \multirow{2}{*}{$\begin{array}{l}\text { Total } \\
\text { Score }\end{array}$} & \multirow{2}{*}{$\begin{array}{l}\text { Mean } \\
\text { Score }\end{array}$} & \multirow[t]{2}{*}{ Rank } \\
\hline & & $\begin{array}{l}\text { Increase } \\
\text { (3) }\end{array}$ & $\begin{array}{l}\text { Same } \\
(2)\end{array}$ & $\begin{array}{l}\text { Decrease } \\
\text { (1) }\end{array}$ & & & \\
\hline 1. & $\begin{array}{l}\text { Participation in group } \\
\text { activities }\end{array}$ & 133(399) & $47(94)$ & 0 & 493 & 2.73 & II \\
\hline 2. & $\begin{array}{l}\text { Participation in village/ } \\
\text { community }\end{array}$ & $82(246)$ & $92(184)$ & $6(6)$ & 436 & 2.42 & V \\
\hline 3. & Team spirit & $91(273)$ & $89(178)$ & 0 & 451 & 2.50 & IV \\
\hline 4. & Communication skills & $156(468)$ & $24(48)$ & 0 & 516 & 2.86 & I \\
\hline 5. & Leadership aspects & $122(366)$ & $58(116)$ & 0 & 482 & 2.67 & III \\
\hline 6. & $\begin{array}{l}\text { Contact with } \\
\text { Government/ officials }\end{array}$ & $47(141)$ & 133(266) & 0 & 407 & 2.26 & VI \\
\hline
\end{tabular}

\section{Nutrition and health wellbeing}

The impact of the project on nutrition and health wellbeing when studied (Table 4). It was found that most of the respondents showed increase in expenses on health care (2.73), sale of food items (milk/ghee/grain) (2.73), availability of milk for family consumption (2.48) and expenditure on other items (purchase of vegetable/grocery etc.) 1.95 consequent of they being covered under the project.

\section{Social empowerment}

The results regarding impact in terms of social empowerment are presented in Table 5.
It was observed that first rank was given to the communication skills (2.86) by the respondents. Second rank was given to the participation in group activities (2.73) followed by leadership aspects (2.67), team spirit (2.50), participation in village/community (2.42). Lastly it was impact in terms of contact with government/officials (2.26) consequent of the project. It may be summarized that project could lay impact on different aspects of the respondents. Conclusively, majority of the respondents reported increase in respect in family, increase in in understandability, confidence in dealing family issues, decision making in buying and selling of grain and animal, increase in expenses on health case, 
sale of food items like ghee and milk and confidence and improvement in communication skills.

NATP had impact in the form of increase in income, expenditure and saving in terms of economic aspects and unique recognition in family, understanding and solving problems, confidence to deal family issues, buying and selling valuables, expanses on health care, expenditure on food items and communication skills. Most of the respondents marked increasing understanding and solving problems independently risk taking ability and visualizing things, respect/person worth/unique recognition, selfrespect in the community which can improve the psychological status of the women towards wellbeing.

\section{References}

Chikwendu, D. Okey. (2002). Impact of Different Agricultural Extension Systems on Farmers in Nigeria. Journal of Extension System, 18; 13-21.
Deepti. 2008. Impact Assessment of All India Coordinated Research Project (AICRP) in Home Science on farm women. M.Sc. thesis, CCS Haryana Agricultural University, Hisar.

Deori, R. and Sethi, N. (1994). Impact of home science technologies transmitted by College of Home Science to farm women in Haryana. (Ab) National Convention of Home Science and Symposium on Home Science for Rural Development. Dec. 15-16, 1994. CCS Haryana Agricultural University, Hisar.

Hirevenkanagondar, L.V., Maroo, K., Chandargh, D.M., Mugali and Maraddi, G.N. 2005. Role of co-operatives in empowerment of women. Proceedings: ISEE National seminar on green to evergreen: Challenges to extension education. December 15-17, 2005.

Yadav, L., Jayanti, Neetima, Vandana. (2005). Capacity-building of farmwomen through SHGs. Proceedings: ISEE National seminar on green to evergreen: Challenges to extension education. December 15-17, 2005.

\section{How to cite this article:}

Ella Rani, Vandana Verma and Binesh Goyat. 2018. Impact of Social determinants on WellBeing of Women. Int.J.Curr.Microbiol.App.Sci. 7(04): 3249-3253.

doi: https://doi.org/10.20546/ijcmas.2018.704.368 